\title{
Emergency Cricothyrotomy: Revised anatomy and its implications for clinical practice
}

\author{
Nutbeam, $T$
}

http://hdl.handle.net/10026.1/8631

10.1136/emermed-2016-206402.60

Emergency Medicine Journal

BMJ

All content in PEARL is protected by copyright law. Author manuscripts are made available in accordance with publisher policies. Please cite only the published version using the details provided on the item record or document. In the absence of an open licence (e.g. Creative Commons), permissions for further reuse of content should be sought from the publisher or author. 


\section{EMERGENCY CRICOTHYROTOMY: REVISED ANATOMY AND ITS IMPLICATIONS FOR CLINICAL PRACTICE}

T Nutbeam, ${ }^{1,2}$ D Enki, ${ }^{2}$ R Clarke, ${ }^{3}$ T Luff, ${ }^{3}$ D Gay ${ }^{3}$. ${ }^{1}$ Emergency Department, PHNT, Plymouth, UK; ${ }^{2}$ University of Plymouth, Plymouth, UK; ${ }^{3}$ Department of Radiology, PHNT, Plymouth, UK

\subsection{6/emermed-2016-206402.60}

Objectives \& Background Emergency cricothyrotomy is a common feature in all difficult airway algorithms. It is the final step following failed attempts to oxygenate a patient. It is rarely performed and has a significant failure rate. The size of the cricothyroid membrane (CTM) has been previously reported in the literature. There is variation in the reported size of this membrane, especially across population groups. Procedure failure may result from a discrepancy between the size of the equipment used and the size of the CTM.

Methods An initial sample of 61 trauma CT scans were reviewed by two radiologists independently. Electronic calipers were used to measure the maximum height of the CTM. This sample was used to power further data collection by assuming a $5 \%$ level of significance with $95 \%$ confidence interval and precision of $0.2 \mathrm{~mm}$-further scans were reviewed until a sample size of 478 patients was achieved.

Results The median height reported was $5.85 \mathrm{~mm}$ (female) and $7.65 \mathrm{~mm}$ (male). These dimensions are much smaller than previously reported in the literature for Western patients. The external diameters of commonly used tubes used to pass through the CTM were compared with these measurements.

Conclusion The CTM in this population is smaller than previously reported. Practitioners encountering patients who may

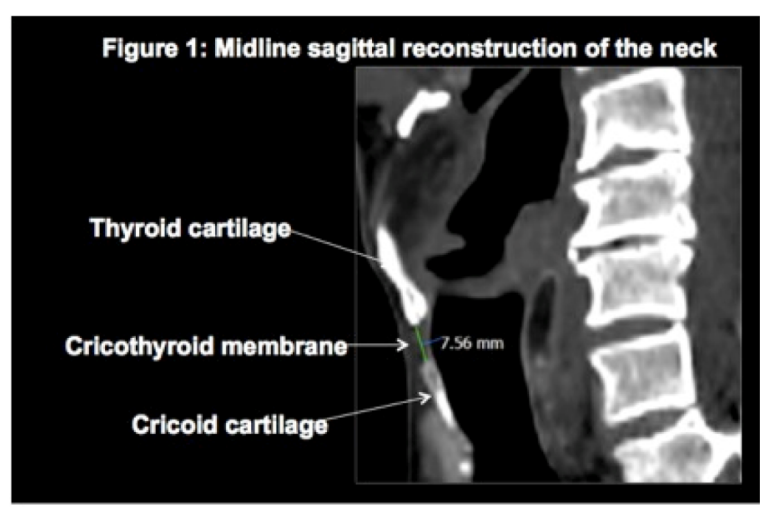

Figure 1

Table 1 Comparison of surgical airway devices, their external diameter and the percentage of population in which CTM height>external diameter of device

\begin{tabular}{lll}
\hline Tube Type & External Diameter & $\begin{array}{l}\text { \% of population in which } \\
\text { CTM height>external } \\
\text { diameter of device }\end{array}$ \\
\hline $6 \mathrm{~mm}$ & 8 & 36.2 \\
$5 \mathrm{~mm}$ & 6.7 & 60.5 \\
$4 \mathrm{~mm}$ & 5.6 & 77.6 \\
$3 \mathrm{~mm}$ & 4.2 & 93.2 \\
Shilley & 10.8 & 7.7 \\
Melker & 8.2 & 34.6 \\
TracheoQuick & 5 & 86.5 \\
\hline
\end{tabular}

require a surgical airway should be aware of this. Rescue airway equipment of a smaller external diameter should be immediately available if required. 

CLINICAL PRACTICE

T Nutbeam, D Enki, R Clarke, T Luff and D Gay

Emerg Med J 2016 33: 933

doi: 10.1136/emermed-2016-206402.60

Updated information and services can be found at:

http://emj.bmj.com/content/33/12/933.1

\section{These include:}

Email alerting service

Receive free email alerts when new articles cite this article. Sign up in the box at the top right corner of the online article.

Topic Articles on similar topics can be found in the following collections

Collections

Clinical diagnostic tests (1056)

Radiology (1002)

Radiology (diagnostics) (903)

\section{Notes}

To request permissions go to:

http://group.bmj.com/group/rights-licensing/permissions

To order reprints go to:

http://journals.bmj.com/cgi/reprintform

To subscribe to BMJ go to:

http://group.bmj.com/subscribe/ 